\title{
Concept, Ritual, and Executive--Paths to Ecological Protection for Mount Tai in Ancient China
}

\author{
Su Bing \\ Foreign Languages School, Tai Shan University, Taian City, PR. China, 271000
}

Keywords: Concept; syncretism; ecology; Mount Tai

Abstract: The Chinese in ancient times have proposed the concept of syncretism between heaven and man, therefore the scholars such as Confucius and the emperors in different dynasties had created various concepts of environmental protection, which have put a great impact on the protection of Mount Tai's ecology. Historic cases of ecological protection of Mount Tai have aroused modern Chinese ecological sense and supervised the governmental decision-making.

\section{Introduction}

Historically, the Chinese people have been aware that the environment and biological resources could be conserved by the setting aside of certain regions for conservation. For example, felling and grazing were forbidden in geomantic forests near villages and towns, on divine hills and forests, around temples, and near ancestral halls and tombs. The hunting grounds, gardens, and parks established by feudal rulers of past dynasties for sight-seeing and pleasure had the secondary function of protecting animal and plant resources, especially the rare species.

Mountains, especially, have been a prominent motif in the progress of Chinese civilization. They traditionally represent divinity and are believed to exist - both in the spiritual and physical sense-on Earth, in Heaven, and the netherworld. Mountains, therefore, command great reverence within traditional Chinese culture. The great sages in ancient China usually regarded mountains as the nursery of the botanical world, habitat of the animal kingdom, and the foundation of human existence. From their perspectives they embodied justice and selflessness: they sustained all living creatures and life forms in the universe, and they bridged Heaven and Earth by generating winds and clouds. As such, mountains actually embody the concept of human benevolence.

To Chinese Buddhists and Taoists, mountains are the domain of deities, and consequently, appropriate settings for religious cultivation. To commoners, they are a source of livelihood and have also been regarded as divine guardians of earthly happiness. Ancient rulers always looked to 
the mountains for guidance as to the Mandate of Heaven. Among China's innumerable mountains are those known as "sacred," "celestial," "famous" and "great". One, however, Mount Tai, has commanded supreme status over all of them since ancient times. This is not because of its $1,500 \mathrm{~m}$ altitude, or its beautiful scenery. The majestic ethos of Mount Tai is generated by its unrivaled cultural heritage and profound history.

\section{Mount Tai: from Myths to Status}

Among China's ancient myths, one tells the tale of the Yan Emperor's litter daughter who drowned while playing in the East Sea. The girl's spirit lingered on and changed into the mythical bird called Jing Wei who tried to fill up the sea with pebbles and twigs she brought from the Western Mountain. She kept on flying between the mountain and the sea until it was finally filled in. Consequently, an island in the sea became a mountain on dry land-Mount Tai-and the creeks that had not yet been filled in became four rivers-the Yellow River, Ji Shui, Wen He and Si Shui, and remaining puddles became lakes and marshland.

Another is the legend of Pan $\mathrm{Gu}$, the first living being and the creator of all in some versions of Chinese mythology. In the beginning, there was nothing in the universe except a formless chaos. This chaos coalesced into a cosmic egg. Then Pan Gu was born into it. The separation of the sky and the earth took eighteen thousand years. The Yang which was light and pure rose to become the sky, and the Yin which was heavy and murky sank to form the earth. Between them was Pan Gu, who went through nine changes every day, his wisdom greater than that of the sky and his ability greater than that of the earth. Every day, the sky rose ten feet higher, the earth became ten feet thicker, and Pan Gu grew ten feet taller.

Eighteen thousand years passed, and there was an extremely high sky, an extremely thick earth, and an extremely tall Pan Gu. After Pan Gu died, his head turned into the Five Sacred Mountains (Mount Tai, Mount Heng, Mount Hua, Mount Heng, Mount Song), his eyes turned into the moon and the sun, his blood changed into the water in river and sea, his hair into the grass.

Mythology is just that-mythology. The emergence of Mount Tai does not attribute to Jing Wei or Pan $\mathrm{Gu}$ in the myths but accompanied by a tremendous upheaval of the earth about 2.5 billion years ago. During the late Mesozoic Era over 100 million years ago, as a result of the compression and under-thrust plate and under the influence of the Yan Shan Mountains movement in North China, the huge Tai Qian fault, stretching 100 kilometers from Lai Wu to Tai An, rose sharply to form a tilted fault-block mountain sloping from south to north, formed the mountain's rugged crags and precipitous cliffs.

For thousands of years, Mount Tai has held the supreme position among the five sacred mountains. Furthermore, inscriptions on its cliffs use such laudatory descriptions as "towering majesty in the east," "supporting the sky and holding up the sun.” Mount Tai stands majestic and fully deserving the honor of the oldest of all mountains. So, since antiquity, it has been called "Tai Shan”(Greatest Mountain) or “Dai Zong”(the oldest of Large Mountains). 
The name "Mount Tai" was first used in a poem in the ancient Book of Odes · Eulogy for the State of $L u$, written in praise of the king of Lu's victories: "Mount Tai is so majestic that all the people of Lu can see it clearly if they raise their heads."1

As the word "Tai" means "large, unobstructed and peaceful," the name "Mount Tai” can mean the largest of mountains, a mountain touching the heavens, and a mountain of stability.

The majesty of Mount Tai has profoundly moved many visitors of every age-emperors who took themselves as the son of heaven, proud high-ranking officials, brilliant poets, and ordinary people too.

Some 2,000 years ago when Liu Che, the Emperor of the Western Han Dynasty(206B.C.-24A.D.) famed for his great talent and bold vision, toured the mountain, he was overwhelmed by its heroic presence and in one breath express eight reactions: "Towering! Majestic! Great! Grand! Glorious! Startling! Incredible!”

\section{The Syncretism between Heaven and Man: Confucius’ Reverence towards Mount Tai}

Confucius was named Kong Qiu; a given name referred to Mount Ni Qiu, which is southeast of Qu Fu City. It said that his parents went to Mount Ni Qiu to pray to the mountain god. On the way back they stopped to rest in a cave, where the mother suddenly gave birth to Confucius. Born from the prayer to a mountain and named after the mountain, the legend of the birth of Confucius is linked with a kind of primitive mountain worship. The philosopher gorged an indissoluble bond with mountains that lasted a lifetime and was so sensitive about the image and spirit of mountains.

In 484 B.C., Confucius began to edit the Book of Odes, China's first collection of poetry. The last poem in the volume entitled Praise-Odes of $L u$. It is the longest poem with 142 sentences and 482 characters. One verse titled Bi Gong as follows:

The mountain of Dai is lofty,

Looked up to by the State of Lu.

We grandly possess also Gui and Meng;

And we shall extend to the limits of the east,

Even the States along the sea.

The tribes of the Huai will seek our alliance;

All will proffer their allegiance:

Such shall be the achievements of the Marquis of Lu. ${ }^{1}$

This verse gives us an insight into the status of Mount Tai in the minds of the people of Lu. By means of metaphor, the poem describes Mount Tai as the symbol of rule by virtue and tire, admired by all eastern states. To Confucius, Mount Tai was not just the home mountain of his native Lu, but also the symbol of the Zhou Ritual, complete in every respect; it was a sacred mountain of spirit and culture.

Confucius' reverence towards Mount Tai greatly influenced by the concept of ancient Chinese environmentalism: "the syncretism between heaven and man", which is the origin of nature worship. In fact, back in the infancy of mankind society, conflicts between man and nature have already yielded. Because of nature worship and animism, ancestors in China created the spirits such 
as God, Emperor of heaven, Ancestral gods, mountain god, river god and sea god for their sacrifice, divination, and worship which have reflected a "manifest destiny", the earliest concept of heaven and human. At that time, the stone worship, mountain worship, sun worship, and totemism are the awe and veneration of the nature held by the ancestors. For example in the "Dawenkou Culture Site”, which locates in the outskirts of the town of Taian City, south of Mount Tai, the artifacts excavated from the ruins in the vicinity of Mount Tai were painted with the shapes of the sun and the moon and Mount Tai. Some scholars believed that such worships, especially mountain worship have put great impact on Confucius, though he lived in $\mathrm{Qu} \mathrm{Fu}$, the capital of Kingdom of Lu, which is only 100 kilometers away from Mount Tai, his repeated visits to the mountain have not only affected his aesthetic ideas, also affected his view of the ecological protection. $\square$

Yi Ching, also known as the Classic of Changes, one of the oldest of the Chinese classic texts, was reinterpreted as a system of cosmology and philosophy that subsequently became intrinsic to Chinese culture. It centered on the ideas of the dynamic balance of opposites, the evolution of events as a process, and acceptance of the inevitability of change, especially the notions of "time" and "the syncretism between heaven and man" has been inherited by Confucius, who had put his assertion about a relationship between man and heaven in his book Commentaries on Yi. In this book, the term of "sky and heaven" literally means the daytime and the night, also implies the moon, the sun, and the stars, and the "natural law" signifies the alternating four seasons. Here is a famous dialogue between him and $\mathrm{Zi} \mathrm{Lu}$, one of his students written in that book:

Confucius: "I have nothing to say."

Zi Gong: "If you speak no more, what could we quote for you?"

Confucius: "The heaven doesn't speak, but the four seasons are alternating and all the creatures are living forever. What exactly has the heaven announced?"2

During Confucius' visit Mount Tai, he met a strange old man named Rong Qiqi(571B.C.-474B.C., born in Cheng State in the Spring and Autumn Period), who might be a hermit on the mountain. Wearing deerskin, sporting a long silver beard, sitting on a rock, he was singing merrily as he was playing the harp without any decoration or carvings. Confucius bowed to him and asked, "Sir, why are you so happy?” The old man answered, "There are many things that I'm happy about, but three of them are essential. One, God has created many creatures, and man is the most precious of all. I'm happy that I was born a man. Two, man is divided into male and female, and social norms consider males superior to females. I'm happy that I was born a male. And three, the lifespan of man is predestined, and some people die very in young. I'm happy that I've lived through to my 95th year." ${ }^{3}$ Rong carried on to say that poverty is the destiny of the learned and that death is the destination of life. So what worry and regret should a man have, as long as he lives according to his destiny before attaining his final destination? Rong's words were heartily endorsed by Confucius, thinking that Rong was a man good at consolation and self-satisfaction.

Confucianism, Confucius' thought, demonstrated also the relation of notions between "people-oriented" and "all is love". It emphasizes the value of life, that is to say, human, the wisest of all creatures should be friendly to all the lives in the world. In Confucius' view, the human could not isolate from nature to survive, so human interests are closely connected with nature. Therefore, human should take care of nature, because it is also a way to cherish their own lives. Confucius's 
thought is human-oriented, but it's not human-centered, because where we can see the human existence and the natural existence. Confucius Ana wrote a story about Confucius and his watchdog:

Confucius's watchdog died, he was sad and told Zi Gong: "If a riding horse died, it should be buried with cloth covering its body; And if a watchdog died, its body should be wrapped by awning cloth and buried. I have heard that the shabby clothes should be kept to bury a dead horse, the worn-out awning cloth kept for burying a dead dog. At present we have no awning cloth, you had better bury the dead dog wrapping with grass mat lest the dirt will directly be put on its head.”3

Confucius' aesthetics could be illustrated by his dictum "The benevolent take delight from the mountains and the wise from the waters. The wise are active; the benevolent are tranquil. The wise are joyful; the benevolent are long-lived."2 Confucius was a wise man, he loves the water; Confucius was benevolent, so he enjoys mountains. In his world, beyond the books from the libraries and etiquette in the courts, nature was the source to inspire the human and breed their intelligence. Therefore, as a famous educator, Confucius was also an ecological pioneer.

Zi Gong, Confucius' cleverest student, once asked him: "Why does the benevolent take delight from the mountains?" The sage replied: "You see, the grandeur of the mountains brings them the respect and admiration of people. All kinds of plants grow on them. Birds and animals live and multiply in their forests. Mountains produce many mountain treasures and contain all kinds of mines. And they are also good places for great scholars and eminent people to retreat from the world. The greatness of mountains is that they never tire of supporting all lives and never begrudge providing for the needs of the people around. The winds and clouds that emerge from the mountains become the breath of life that fills the world. If there were no mountains to provide people with their needs, how could countries come into being? This is why the benevolent take delight from the mountains."

\section{Chai Wang: The Oldest Ritual on Mount Tai}

During the Spring and Autumn Period (770B.C.-476B.C.), Duke Huan (King of the State of Qi, 685B.C.-643B.C.) became a powerful ruler among the States; he wanted to hold a grand ceremony on Mount Tai to offer sacrifices to heaven. But his high official named Guan Zhong told him, "I have heard that there are 72 virtuous monarchs who had held such ceremony on Mount Tai; Do you think you are a virtuous monarch?” ${ }^{5}$ In fact, Guan Zhong implied that Duke Huan was not qualified to follow in their footsteps.

It is hard to prove the truth of the number of 72 virtuous monarchs in Guan Zhong's words, but the ceremony to offer sacrifices to heaven and earth on Mount Tai was a special religious event with a foundation in a long history.

The tribal chieftains and monarchs in pre-Qin era naturally stood in awe of Mount Tai by holding a ceremonial called "Chai Wang", which originally recorded in the Book of History, China's most ancient text. The book has described a set of religious rites performed when Shun succeeded Yao as a leader of the allied tribes in the late period of the patriarchal society. The ceremonial process included: first, worship of the supreme god, then the heavenly gods of the sun, 
moon, and stars, and the earthly gods of the mountains, rivers, and seas. The mountain here referred to the large ones on earth, the chief of which was called Dai Zong--Mount Tai.

As the leader of the allied tribes, Shun made an inspection tour across the whole country every five years. Usually, in spring, he inspected Mount Tai, called the East Sacred Mountain. When Shun visited Mount Tai, he climbed to the summit and lit the ceremonial fire with his own hands. The dense smoke rose high in the sky, mingling with the clouds. The rising smoke was the way that Shun sent the message to heaven by which he was administering affairs on earth and asking for its blessing on behalf of heaven. This ceremony was called "Chai", meaning to burn firewood to worship heaven.

Then Shun would look out onto every direction one after the other. At the same time, the chieftain of all the tribes would all climb to the top of the mountains in their regions and worship toward Mountain Tai. This was called "Wang”, meaning to Gaze out to the mountains and rivers.

The whole ceremonial was called "Chai Wang”. At present, a plaque carving the words "Chai Wang Yi Feng” is keeping in the Jade Emperor Temple on the summit of the Mount Tai as a reminder of this holiest religious and political ceremony.

The reason for these ancient rulers to select Mount Tai as the foremost of mountains and the site for such grand ceremonies owns to the importance of Mount Tai in China.

Mount Tai's geographical position and environment are integral to its prominence. It stands on the North China Plain, the vast Yellow Sea to its east and the torrential Yellow River to its west. Though its altitude, at 1,545 meters above sea level, is unremarkable, it, nonetheless, towers awesomely above the surrounding low hills and at lands, by virtue of a difference in height of more than 1,300 meters. Its range extends for hundreds of kilometers, which in addition to its seemingly majestic height brings to Mount Tai an overall ethos of magnitude and solidity.

In ancient times, the Central Plains area had a sacred mountain in each of its five directions Mount Tai in the east, Mount Hua in the west, Mount Heng in the north, Mount Song in the center, and Mount Heng (a different character) in the south. Within ancient philosophy, the east is considered the most important, as it is where the sun rises and where the Yin and the Yang meet to create all forms of life in the universe; it is the place of hope, vitality, and auspice. Mount Tai, therefore, was honored as the leader of the five sacred mountains and always remained in this supreme position.

Its supremacy is best exemplified by ancient worship ceremonies of Chai, and Wang held on the mountain. They were the highest and most important worship ceremonies before the feudal society (475B.C.-1840A.D.) in ancient China, one that was enacted by the tribal chieftains, monarchs and kings in honor of Heaven and Earth, allowing them to take the worship of the sun, the worship of the east, and the mountain worship of primitive religion and roll them all up into Mount Tai worship. With the dawning of a civilization on the land west of the Pacific, Mount Tai naturally became a sacred spot to the Chinese ancestors, The Jade Emperor Summit that was as close to heaven as you could get, an open palace giving the first view of the rising sun. 


\section{Feng Shan: Altar of Mount Tai Worship for Emperors to Pray Heaven}

According to Guan Zhong ${ }^{5}$, the last of the 72 ancient rulers to pay sacrifice on Mount Tai was King Cheng, the second ruler of the Western Zhou Dynasty $\left(11^{\text {th }}\right.$ century-771B.C.) in the $11^{\text {th }}$ century B.C. If what he said was right, by the time the First Emperor of Qin (221.B.C.-210B.C.) visited Mount Tai in 219 B.C., more than 800 years had gone by without any ceremony being held. During those eight centuries, tremendous historical changes took place, including a second massive integration of people, and the transition from slavery and dukedoms to a centralized feudal system.

In the Warring States Period, farsighted statesmen and thinkers foresaw that a newly united country, superior to what had gone before, was dawning on the eastern horizon. Zou Yan, a thinker at the Ji Xia School in Lin Zi, the capital of Qi State(11 century B.C-221B.C.), not northeast of Mount Tai, put forth a theory on "Yin and Yang and the Cycle of Five Virtues"7 that formed the theoretical foundation for the emergence of a new united country. Zou held that the country would never be ruled by one single family, and that change of rule was a result of the interaction of the five elements that controlled the universe-metal, wood, water, fire, and earth. When one old dynasty declined, a vigorous new one, one more suited to needs of the times, would rise to replace it. This was acting in compliance with heaven's will.

The best way to announce to the world that rule had been transferred was to hold a ceremony on Mount Tai. Since the time immemorial, Mount Tai had been the holy altar where rulers reported to heaven. The other was that since this foremost of mountains stood in the east where, according to the five element theory, Yin and Yang alternated, where all things had their genesis and growth, the birth of a new dynasty should be legitimized by holding a "mountain worship"7 ceremony on Mount Tai, so that the heaven would have the blessing from the heaven.

An inscription on the cliff near the South Gate to Heaven extols Mount Tai as the "place nourishes all things, and rises up to the height of heaven”. This is a good illustration for Mount Tai to be the supreme sacred altar for the performance of sacrificial rites to heaven by ancient emperors. No other mountains in China were deemed worthy of such an honor.

The "mountain worship" ceremony to offer sacrifices to heaven and earth had the same religious and political significance as the Mount Tai "Chai Wang" ceremony but in a changed form.

The Chinese words for "mountain worship" are "Feng Shan"5. Here the "Feng" element of the rite involved building soil into an altar mound on the summit, onto which the ruler would climb and pray to heaven, a sign to announce the legitimacy of his reign. Essentially it was the same as "reporting” in the "Chai Wang” ceremony.

The "Shan" element involved a patch of land being cleared on a hill below Mount Tai and used to express gratitude to earth. This ceremony also proclaimed the ruler's legitimate ownership of land, mountains, and rivers, and had the same connotations as the ceremony of "gazing out on the mountains and rivers." 5

So we can conclude that the "Feng Shan" and "Chai Wang" ceremonies both used the name of heaven so as to declare the emperors' legitimate rule over the land and the people. Rites associating 
political legitimacy with the supernatural were summarized by ancient thinkers as "teaching and ruling the people by imitating the way of the gods." 5

The First Emperor of Qin unified China in 221 B.C.; three years later he ascended Zou Yi Hill in the southeast of Zou Xian County, Shan Dong Province. Since no "mountain worship" ceremony had been held for 800 years, neither the emperor nor his entourage had any idea of what it should be like. So the emperor called 70 Confucian scholars from the former State of Lu to discuss.

Their ideas were nebulous to him, so he dismissed them all impatiently, he decided himself what form worshipful ceremonies should take. He had a vehicle path built up the mountain, held the "mountain worship" ceremony of "Feng", which contains elements of the rite involved building soil into an altar mound on the summit, onto which the ruler would climb and pray to heaven, a sign to announce the legitimacy of his reign. After the praying, the emperor erected a stele on the summit. This was where he performed the veneration of Heaven. The inscription on the stele was written by Li Si, an accomplished Qin Dynasty politician, writer, calligrapher and prime minister. In it, he eulogizes the great achievements of the first emperor, and how qualified for him to be given the honor of conducting such ceremonies. The inscription was carved in Li Si's handwriting on the stone stele, which first stood at the summit of Mount Tai and was later moved to the Dai Temple at its foot. It is still there, but the inscription is barely decipherable.

Then he descended from the north side, catching in a downpour. He rushed to take shelter under a big tree, which he later honored with the title "Wu Da Fu"(ninth rank official during the Qin Dynasty). The rite of "Shan" dedicated to Earth took place at Mount Liang Fu nearby. Since then, Mount Tai was promoted from a sacred mountain worshiped by tribes in the east to one worshiped by all the peoples of China and became a holy symbol of national unification.

In the West Han Dynasty(206B.C.-24 A.D.), Emperor Wu named Liu Che made more trips to pay pilgrim to Mount Tai than any other Chinese emperor. Liu Che is hailed as one of the most accomplished emperors in Chinese history. He settled frontier crises, opened up a trade route to the Western Regions, and led China into a period of great prosperity. During his reign of 54 years, he conducted eight "Heaven and Earth" worship rituals on the mountain. It was in 110 B.C. that Liu Che embarked on his journey to Mount Tai, in celebration of his great political and administrative achievements. After performing the "Heaven and Earth" worship ritual, he then accepted the grand homage paid to him by his ministers and other high-ranking officials. To commemorate this visit to Mount Tai, Liu Che decreed a general pardon, exempted four counties in the Mount Tai vicinity from a year's taxes, and changed his reign title to Yuan Feng, or Original Bestowal. He also set up Feng Gao County, consisting of two former counties, Ying and Bo, whose specific function was to take charge of Mount Tai worship activities and related matters.

Emperor Tai Zong (627A.D.-650A.D.) of the Tang Dynasty, named Li Shimin, was no less an accomplished emperor than Liu Che. He also wanted to make suitable reciprocal obeisance to "Heaven and Earth" on Mount Tai. He planned to go on three occasions, but it was not his destiny to make this sojourn. He was persuaded by his minister Wei Zheng ( (580A.D.-643A.D.), courtesy name Xuan Cheng, formally Duke Wen Zhen of Zheng, was a Chinese politician and the lead editor of the Book of Sui, composed in 636 A.D. He served as a chancellor of Tang Dynasty for about 13 years, during the reign of Emperor Taizong.) to postpone his first trip in the early period of his reign, 
on the grounds that the Mount Tai area had not sufficiently recovered from constant wars to be able to sponsor such a grand ceremony. The next two plans were canceled because of frontier rebellions and floods. The first emperor of the Tang Dynasty to visit Mount Tai was Gao Zong (649A.D.-683A.D.), together with his empress Wu Zetian (684A.D.-705A.D.). His reign marked the first time that the Mount Tai ceremony was ever performed by both an emperor and empress. Gao Zong paid homage to Heaven and Wu Zetian to Earth. The size of their entourage was also unprecedented. Apart from court officials, there were also many foreign envoys. The monument in memory of the event is composed uniquely of double stone steles. It is now in the Dai Temple.

\section{Executive of Ecological Concepts: from the Emperors to the Governors}

In ancient China, there is no such phrase as "ecological protection", 8 but the protection activities at that time were conceptualized by worship ceremonies giving by the emperors on Mount Tai. Emperors in China usually were believed to be the son of heaven, their ceremonies were considered to contain the ritual nature of the State, and Mount Tai became the royal place of sacrifice or the country's altar to heaven and earth, so the emperors in different dynasties thus advocated ecological protection for Mount Tai, "the Head of Five Sacred Mountains", owing to the protection of the worship site.

In addition to the worships of mountains, rivers, Chinese emperors, at a very early time, paid attention to ecological protection. As early as the Xia Dynasty (The establishment of the Xia Dynasty (21st B.C.-17th century B.C.) is an important milestone in the history of Chinese civilization and marks the end of the Primitive Society and the beginning of the Class Society. It is the first dynasty in Chinese history and lasted nearly 500 years, including the reigns of 17 emperors. It is thought that most of the Xia people probably inhabited the western area of Henan Province and southern Shanxi Province.), the court issued a law "prohibitions of Yu", called on people "not to cut trees and mow grass in spring on the mountains to let the plants thrive; and not to cast nets in waters to let the fishes breed."6 This law was supposed to be the first legislation on environmental protection in China. It should be based on the lessons from ancient Chinese people who had engaged in social activities such as hunting and fishing. The lessons are the understandable now but pioneers at that time, that is: the natural resources are not inexhaustible, and should be reasonably and sustainably used. This is the original prototype of ecological civilization.

When the First Emperor of Qin planned to pilgrim Mount Tai in 219 B.C., he called 70 Confucian scholars from the former State of Lu to discuss the right way to worship the Heaven. Confucian scholars all advised the emperor's carriage wheels should be wrapped with cattail so as to avoid harming any of its grasses, trees rock or soil.

In the West Han Dynasty, Emperor Liu Che(140B.C.-87B. C.) visited Mount Tai on eight occasions, at the same times, thousands of trees had been planted on the mountain for his ceremonies. Li Dao Yuan, in his Commentary on the Waterways Classic, said: "In Dai Temple, The cypress trunks are more than 20 arm-spans around, and they were planted by Emperor Liu Che"9. Now the exuberant trees are well-known as the living fossil plants and have been listed as one of the eight best sights of Tai'an City. 
Besides trees left on Mount Tai by Liu Che, the Wordless Stele on the summit was erected by him. In ancient China, the wordless stele was a great honor reserved for those whose merits and virtues were boundless. Therefore, Emperor Liu Che's wordless stele expressed his boundless respect and admiration for the heaven, earth, and Mount Tai.

The wheels of history turned, reaching the Sui Dynasty(581A.D.-618A.D.) and Tang Dynasty(618A.D.-907A.D.). The emperors of the two dynasties continued to hold ceremonies to worship for mountains and rivers, and owing to the worship, Mount Tai had taken the most important role in protecting its natural ecology.

Piles of documents about the ecological protection of Mount Tai can be found in the books and records of the two dynasties. In Record of Emperor Gao Zu of Book of Sui, the imperial decree was announced in December, 600 A. D. that "for Mount Tai has benefited to form rain to water all living things, a temple should be built on it to worship for respect, the ceremonial sacrifice should consist of an ox, a sheep, and a pig, called 'Tai Lao"'10. Various sacrifices were held in Tang dynasty. The Annal of Rites and Music in Old History Book of Tang recorded that the big sacrifice offered to Heaven and Earth, the middle sacrifice offered to the sun, the moon, the stars and mountains, and the small sacrifice offered to the woods and rivers ${ }^{11}$. It is obvious that the sacrificial activities in Tang Dynasty focused more on respect of nature, mountains, forests, and rivers were included in the ritual, which has contained profound implications for public awareness of environmental protection.

In Kaiyuan Period(725A.D.), Emperor Xuan Zong of Tang promulgated a decree to confer “Tian Qi Wang” (Sky King) upon Mount Tai Spirit, the area ten miles to Mount Tai was forbidden to chop and collect firewood, so the first national ecological park appeared in China.

Song Dynasty(960A.D.-1279A.D.) followed the Tang Dynasty's system to offer sacrifices to Heaven and Earth worship on Mount Tai. During the autumn of 1008 A. D., Emperor Zhen Zong set out from Bian Jing (Today's Ka Feng, Henan Province) toward Mount Tai. Approaching Tai An City, the emperor issued proclamation that "the area seven miles around the mountain was prohibited from chopping and collecting firewood, and She Shou mountain and $\mathrm{Cu}$ Lai mountain(the two ranges of Mount Tai) was prohibited either, even the trees in the way to ascend the mountain are not allowed to chop" ${ }^{\prime 2}$. This shows that Song Dynasty has paid more attention to the mountain's original vegetation protection, at the same time, the protection area has enlarged its scope to the ranges of Mount Tai.

In Spring and Autumn period (722 B. C. -476 B. C. ), a river named Si Shui flew through State of Lu located in the south of Mount Tai. One Summer, while the King named Duke Xuan of Lu(Lu Xuan Gong) was net-fishing in Si Shui, one of his carders named Li Ge went ahead and cut the net and said, "Summer is the season for fishes to breed and grow, so it is greedy to catch them with a net.” The King was not irritated but felt happy at Li Ge's deeds, said, "It is good for Li Ge to correct my errors. The broken net becomes meaningful for me to understand the right way to govern the state. I would keep the net and the lessons forever."13 This legendary case, which an official had supervised the King to preserve the ecological fishery, generated a positive impact on the government officials of Mount Tai. 
The governors also have attached great attention to the protection of the source of water on Mount Tai. In September of Zhi Yuan 25 years during the rule of Kublai Khan(1292 A. D., the local official carved the prohibition on the east cliff near Queen Mother Pond for fear that the visitors washed their clothes and polluted the water there. "Anyone who breaks the ban will be flogged 80 times with a stick."

\section{Conclusion}

History is a mirror. When we reflect on ourselves, the so-called modern people, it is obvious that we are facing the direction of our present civilization that is to turn the earth into a garbage dump and then abandon it, to turn it into an uninhabitable smoggy sewer and then leave it. To a large extent what we're doing is committing suicide as a species. To the primitive people, the world is local-cosmological, not planetary. Our ancestors, the emperors, the officials and the celebrities have obtained clever methods and achieved greatly in preserving the environment and biological resources. In the globalization, we can't ascend to the summit of Mount Tai to build an altar and pray the heaven again, except as a cultural attraction. There are two major activities available for us to do. One is restoration ecology as practiced by residents: urban people, suburban people, and rural people. Such ecological restoration projects should be more comprehensive human activities. The other direction is urban sustainability, which calls on more people to become re-naturalized as urban residents ${ }^{14}$. At present, urban sustainability would eventually become the top issue for decision-making and policy directions by the modern governors, because they should be cleverer than our ancestors.

\section{References}

[1] Launcelot Cranmer-Byng. Book of Ode Eulogy for the State of Lu. Nabu Press, 2010.

[2] Yang, Bojun. The Translation and Annotation of the Analects of Confucius. Beijing: Zhonghua Book Company, 1980.

[3] Yang, Chaoming, Song, Chunli. Confucius Ana. Ji Nan: Qi Lu Publishing House

[4] Xiang, Zonglu. Revise of Garden of Anecdotes. Beijing: Zhonghua Book Company, 1987.

[5] Sima, Qian. Historical Records. Beijing: Zhonghua Book Company,1982.

[6] Fan, Dong. Translation and Annotation of Book of History. Shanghai: Shanghai Ancient Books Publishing House, 2012.

[7] Sun, Kaitai. Biography of Zou Yan. Jinan: Shan Dong Literature and Art Press, 2004.

[8] Berg, Peter and Raymond Dasmann, "Reinhabiting California,” The Ecologist 7, no. 10. 1977.

[9] Li, Daoyuan. Commentary on the Waterways Classic. Beijing: Zhonghua Book Company, 2009.

[10] Wei, Zheng. Book of Sui. Beijing: Zhonghua Book Company, 1973.

[11] Liu, Xiang, Old History of Book of Tang. Beijing: Zhonghua Book Company, 1975.

[12] Tuo, Tuo, A, Lutu. History of Song. Beijing: Zhonghua Book Company, 1976.

[13] Zuo, Qiumig. Chinese Classics. Shan Xi Ancient Books Publishing House, 2007.

[14] Berg, Peter. Envisioning Sustainability. San Francisco: Subculture Books, 2009. 